«Da un certo punto della mia vita ho considerato il mestiere o l'arte come una descrizione delle cose e di noi stessi» (Aldo Rossi).

Se guardo al mio percorso non riesco mai a vedere le cose come sganciate dalla vita e quando penso all'arte $\mathrm{o}$ al mio mestiere li vedo sempre legati a fatti reali.

Per descrivere da dove nasce il branco, per esempio, c'è un aneddoto che non posso fare a meno di raccontare: è notte, sono in casa e fuori sento dei cani ringhiare, sono certamente dei gruppi di randagi che provengono dai campi lì intorno per cercare cibo, ma non trovano niente e dopo un po' se ne vanno.

Passata la paura di quel momento a me resta però impressa quella visione, forte, fortissima: è l'immagine di gruppo di animali che attraversa la Sicilia in una campagna bruciata e desolata. È solo dopo quell'apparizione notturna che continuo a rivedere quei cani come dei fantasmi, pronti ad incutere paura, a impossessarsi di un luogo, a occuparlo e poi abbandonarlo.

Al di là dell'aspetto "terrificante", mi domando dunque se quelle ombre notturne non assomiglino forse invece a quelle di persone reali: come quelle di uomini e donne che cercano il modo di mettersi in salvo, individui che come dei nomadi si muovono fra mondi diversi e si distinguono tra loro solo per differenza di razza, lingua o abitudini e anche se sono molto uniti tra loro, resistono e si muovono in nome di un unico scopo: saper sopravvivere alla fame.

È su questo precario equilibrio di relazione interna che si regge il branco, il branco dei cani randagi è una struttura autonoma anche se animata da tensioni che si traducono spesso in gesti di forza e sguardi di rispetto, un legame che tra gli animali è condizionato anche dalla capacità che hanno di rapportarsi al capobranco e anche questa in fondo non è nient'altro che una terribile metafora che tante volte ci è toccato rivedere nella storia, presente e passata.

È la dinamica di una regola politica eterna e ripetitiva che spinge l'animale o l'uomo che sia, indifferentemente, ad aggregarsi con gli altri, per stare meglio, per difendersi, per condividere e trovare il proprio habitat nel nome di un equilibrio comune, equo e democratico.

Per i cani questi luoghi di difesa e aggregazione sono spazi semplici e sempre improvvisati, come il sagrato di una chiesa o tra le sterpaglie di un campo abbandonato oppure ancora un capannone in disuso in una qualsiasi periferia urbana; purtroppo non sono rari i casi in cui anche per l'uomo è così e questi rifugi si tramutano per necessità in vere e proprie dimore. È il racconto della vita ai margini. È il racconto della vita ai margini, con un percorso che si snoda fra avanzi e macerie di città, in luoghi di transizioni come le grandi città di porto del mediterraneo che sono le vere protagoniste di queste narrazioni, le stesse che ho dipinto quando ho cominciato a realizzare le prime sculture dei cani. Le città che avevo rappresentato in quel periodo e per tutti gli anni novanta, sono state anche uno dei temi che ho approfondito maggiormente, a cominciare proprio da quelle portuali. Nelle città di porto la stratificazione architettonica lascia tracce chiare di un passato storico complesso e diversificato, le pietre e gli edifici sono infatti le testimonianze concrete di una modifica connessa alle esigenze e alla natura di quel luogo, dovute a necessità di tipo commerciali, economiche e sociali. Si pensi per esempio in che modo e quanto cambia uno spazio urbano allo sbarco di un nave traghetto che riversa in poche ore migliaia di persone sul suolo di una città che l'accoglie, il tutto si sviluppa e cresce intorno al porto in un continuo cambiamento e si trasforma in poche ore fino a modificarne la struttura. Una "invasione" che nel tempo determina un nuovo assetto culturale. Da questa osservazione nasce il bisogno di dipingere e rappresentare quei luoghi e la scultura ne è la diretta conseguenza, nient'altro che lo sviluppo in tre dimensioni dello stesso pensiero dipinto: è un'immagine che diventa materia.

Anzi, la materia fragile e friabile della scultura potrebbe essere addirittura la stessa della quale sono fatte le case abusive. Forse è per questo che sono attratto da luoghi come Gela, un'antica colonia greca, dove, ora, l'abusivismo edilizio ha sviluppato it peggio di sé e l'ha replicato in modo seriale fino alla nausea.

Ma allora? se queste case nascono in una notte, alla rinfusa e in modo totalmente anarchico perché anche la scultura non potrebbe crearsi abusivamente, rompendo quei divieti accademici che da sempre la vincolano se stessa? Ecco.

Da questa domanda è nato il branco. Da una vera spaccatura col mio pas-

\section{DIALOGUE ABOUT BRANCO}

«From a certain point in my life I considered the craft or art as a description of things and of ourselves" (Aldo Rossi).

When I look at my journey, I never see things as detached from life and when I think of art or my profession, I always see everything linked to real facts.

There is a real-life story that can help describe where branco comes from. It was night and I was at home when I heard a bunch of dogs growling outside, I knew they were groups of stray dogs that came from the fields surrounding the house. They had come around to look for food, but they found nothing and after a while they left.

Soon I got over the initial fear, but a vision endured strongly, very strongly: it is the image of a group of animals crossing a burnt and desolate Sicilian countryside.

Ever since that nocturnal apparition have kept seeing those dogs over and over again like ghosts, ready to strike fear, to take possession of a place, to occupy it and then abandon it. Apart from contemplating the "terrifying" aspect, I wonder if those nocturnal shadows do not perhaps resemble those of real people: like those of men and women who are looking for a way to get to safety; individuals who, like nomads, move between different worlds, and characteristics that distinguish them from each other are race, language or habits. Being close to each other allows them to resist and to move towards a single purpose: winning the battle against hunger.

A herd is based on a precarious balance of internal relations.

A pack of stray dogs is an autonomous structure even if animated by tensions that often translate into gestures of strength and respectful looks, a bond that between animals is conditioned by the ability they have to relate to their leader and this is a mere metaphor for some horrifying events we witnessed in human history.

It is the dynamics of an eternal and repetitive political rule that pushes both men and animals equally to aggregate with others in order to get better, to defend themselves, to find and share their habitat in the name of a balanced, fair and democratic equilibrium.
For dogs, the places of defence and aggregation are simple and improvised, like a churchyard, scrubs of an abandoned field or even a disused shed in an urban suburb. This can be the case for humans too, when by necessity these refuges are transformed into real abodes.

It is a story of life on the margins of society, with a path that winds through the remains and rubble of cities, especially in places of transitions such as large port cities of the Mediterranean that are the real protagonists of these narratives, the same ones I painted when I started making the first dog sculptures,

The cities which I had been portraying in that period and throughout the nineties were in fact one of the themes I have explored in more depth, first of all the port ones. Architectural composition of a port city clearly indicates their complex and diversified past.

The stones and buildings are in fact a concrete evidence of change linked to needs and nature of that place, which revolve around economic and social requisites. Consider, for example, how much and in what way an urban space changes after a disembarking of a ferry ship from which thousands of people debark in only few hours. Everything around the port grows and develops in a continuous process of transformation until its structure is permanently modified. An "invasion" that over time determines a new cultural order.

From this very observation arises the need to paint and represent those places and sculpture is the direct consequence of that practice, nothing more than an evolution of the same thought into three-dimensionality: it is an image that becomes a matter.

Indeed, the fragile and crumbly substance of the sculpture matches the one the illegal houses are made of. Perhaps this is why I am attracted to places like Gela, an ancient Greek colony, where illegal building has manifested its worst face and has replicated itself perpetually.

But then? if these houses are born overnight, in bulk and in a totally anarchic way, why can't sculpture be created illegally, breaking those academic prohibitions that have always binded it to itself? Here it is.

Branco was born from this question. From a real rift with my past, rebuilt with the same building materials as illegal buildings: cement, sand, tar, lead, sheet metal, wire mesh and con- 
sato, ricostruito con gli stessi materiali dell'abusivismo edilizio: cemento, sabbia, catrame, piombo, lamiera, rete metallica e tondino da cantiere, tutto per farne una scultura abusiva. Il soggetto dei cani è stato nient'altro che una conseguenza di queste riflessioni sul significato abusivo e randagio della mia scultura e, allo stesso tempo, mi è sembrata la perfetta metafora della rappresentazione di una società multietnica, in continuo dialogo e movimento.

Un'immagine simbolica di un mondo con relazioni più o meno complicate, tra i singoli e il gruppo, un dialogo serrato fra passato e presente dove il campo d'azione è sempre e comunque il bacino del Mediterraneo, luogo germinale della nostra cultura.

Una riflessione anche e quindi sulle nostre comuni radici dove l'animale è l'inconsapevole e innocente testimone di un innato bisogno di contatto con gli altri, il cui istinto fondante è la fiducia nelle relazioni sociali.

Così per certificare questa intenzione progettuale a ognuno di questi cani ho affidato un titolo, che è il nome di una città fantasma, un luogo realmente esistito e poi abbandonato. Un modo per assegnare agli animali o meglio alle sculture il ruolo di testimoni della più complessa idea utopistica dell'uomo: la città (ovvero un luogo dove vivere e sopravvivere nel migliore dei modi possibili) già esistito e poi abbandonato come Kolmaskop, Hashima, Animas Forks, Africo Bannack, Belchite, Pripyat, Suakin, Kalapana, San Zhi, Mologa, Varosha, Tarcoon, Patton, Mary Murphy, Bradburn, Silverdale, ecc. struction rod, all to make it an illegal sculpture.

The subject of dogs was nothing more than a consequence of these reflections on the abusive and stray meaning of my sculpture and, at the same time, it seemed to me the perfect metaphor for the representation of a multi-ethnic society, in continuous dialogue and movement.

A symbolic image of a world with more or less complicated relationships between individuals and groups, a close dialogue between past and present where the field of action is always the Mediterranean basin, the germina place of our culture.

A reflection on our common roots where the animal is an unconscious and innocent proof of an innate need for contact with others and who is inclined by basic instincts to trust in social relationships.

So to validate this contemplation entrusted each of these dogs a title, which is a name of a ghost town, a place that had really existed and then was abandoned. By doing that, I assigned the roles of witnesses of the most complex utopian idea of a man to animals, or rather to sculptures: the city (i.e. a place to live and survive in the best possible way) which had existed and then was abandoned as Kolmaskop, Hashima, Animas Forks, Africo Bannack, Belchite, Pripyat, Suakin, Kalapana, San Zhi, Mologa, Varosha, Tarcoon, Patton, Mary Murphy, Bradburn, Silverdale, etc.

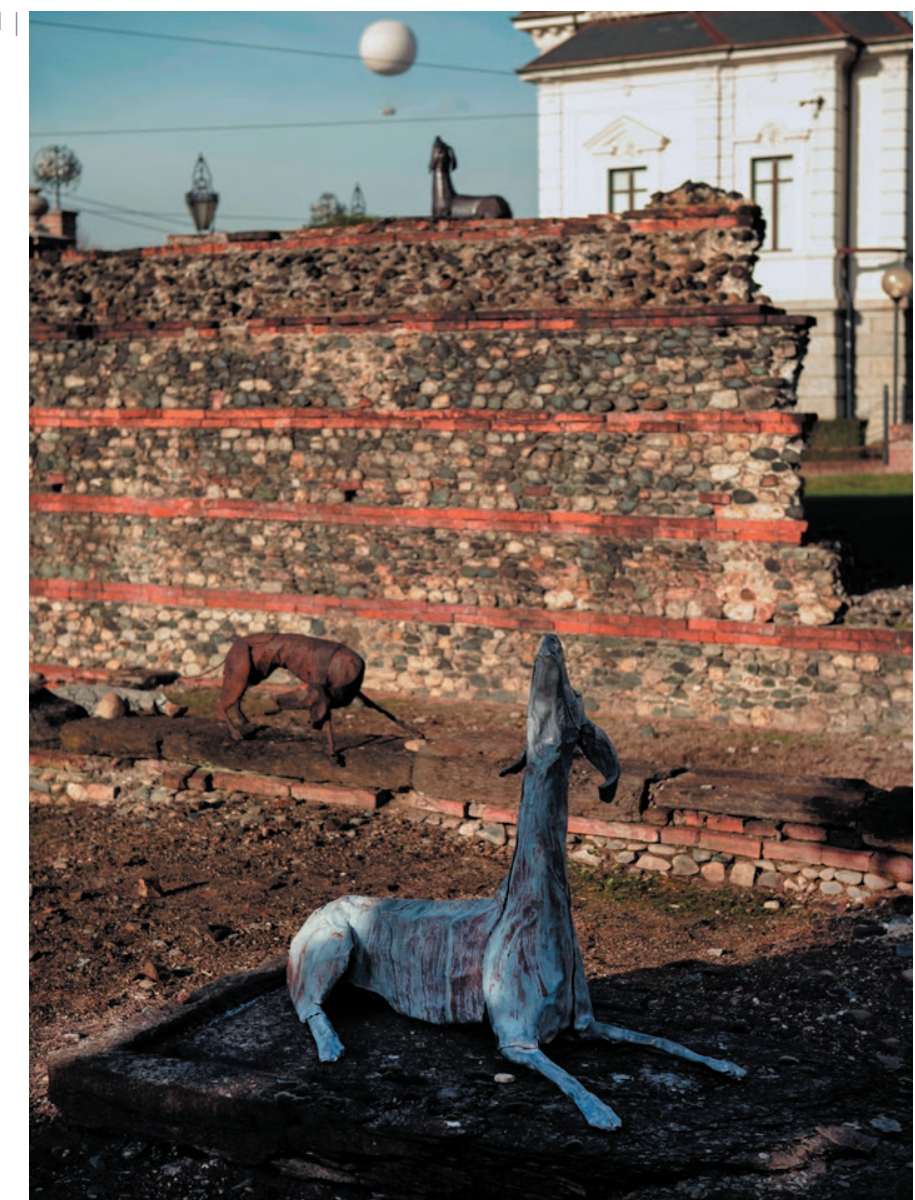

01 | Sabauda Torino, 2013 Sabauda Torino, 2013

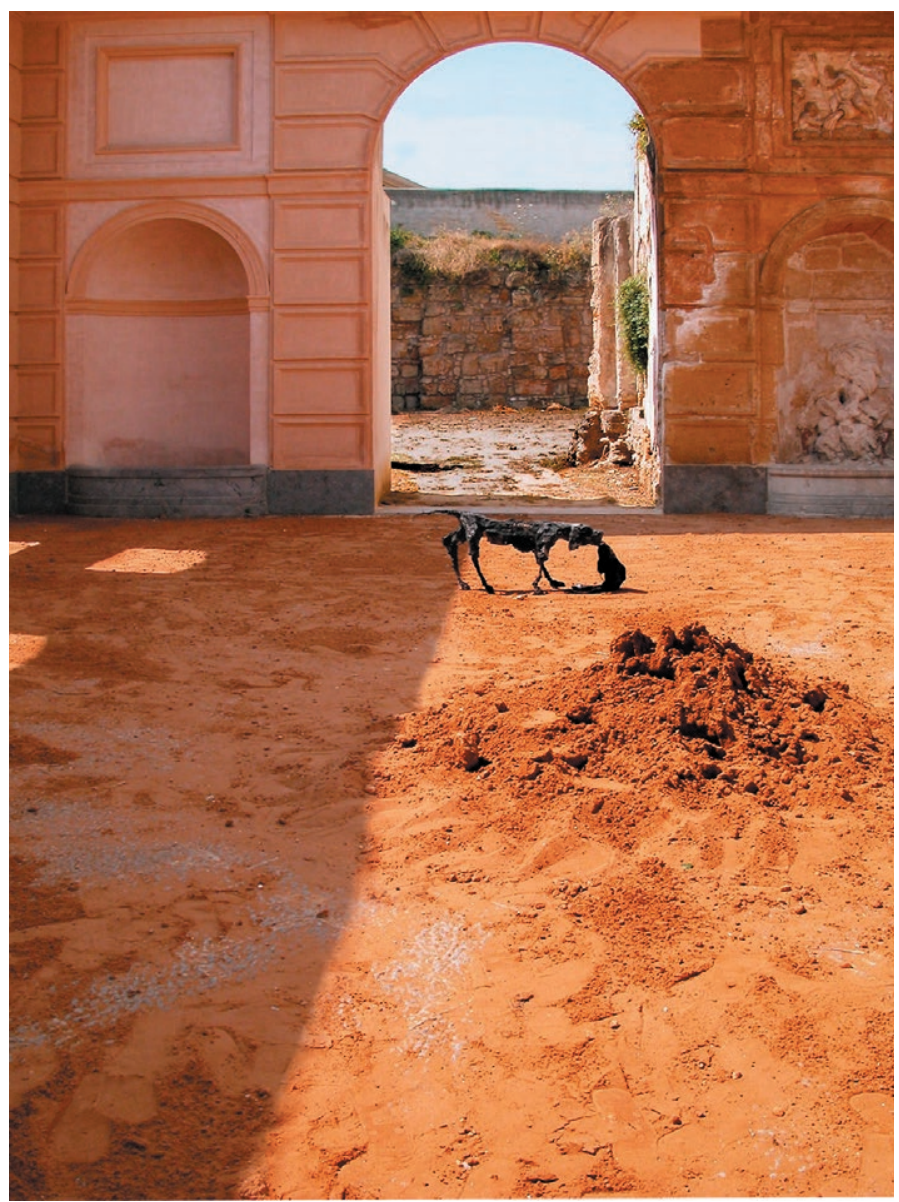

02 | Extramoenia Palermo, 2004 Extramoenia Palermo, 2004 
03 | Sabauda Torino, 2013 Sabauda Torino, 2013

04 | Extramoenia Palermo, 2004 Extramoenia Palermo, 2004
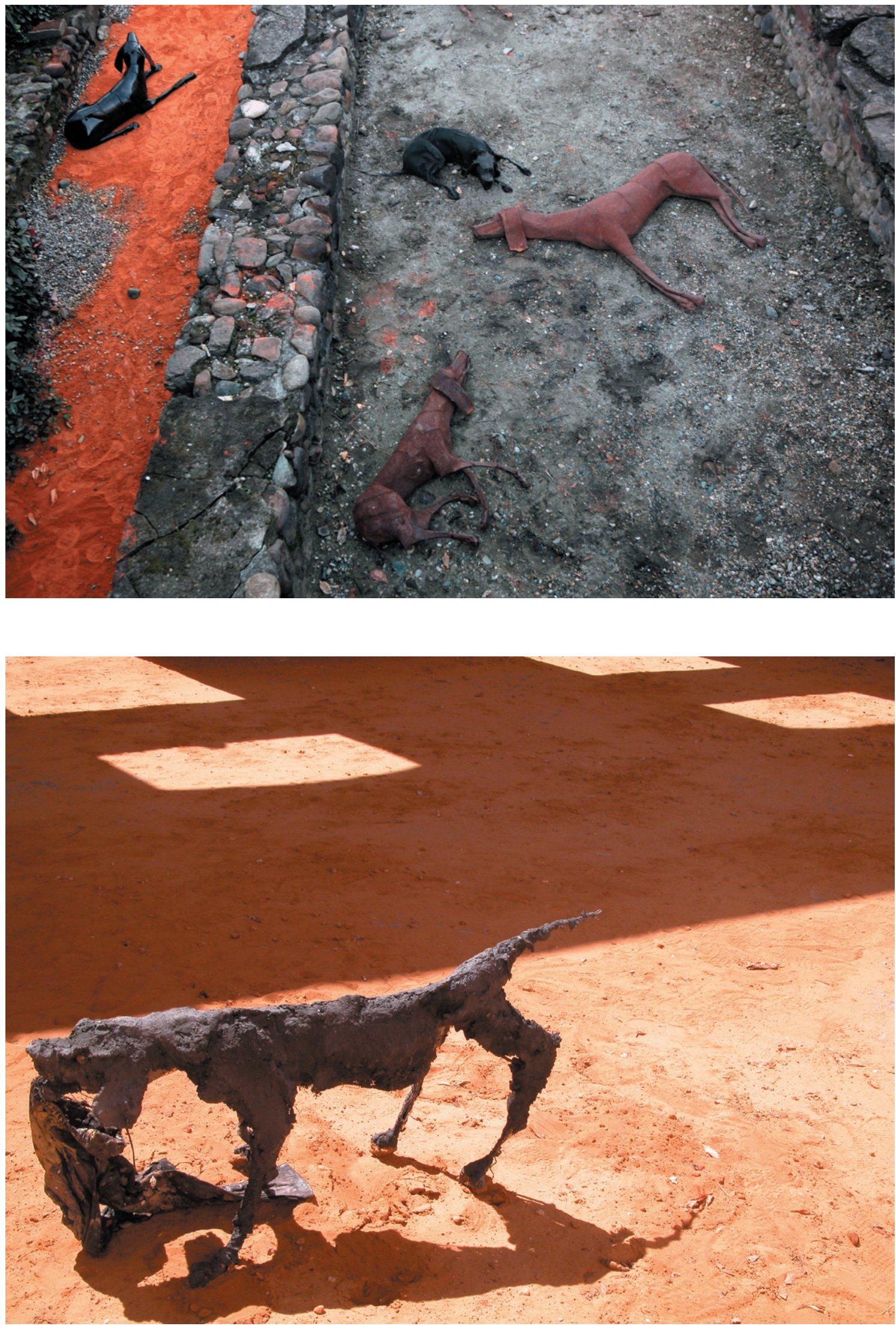

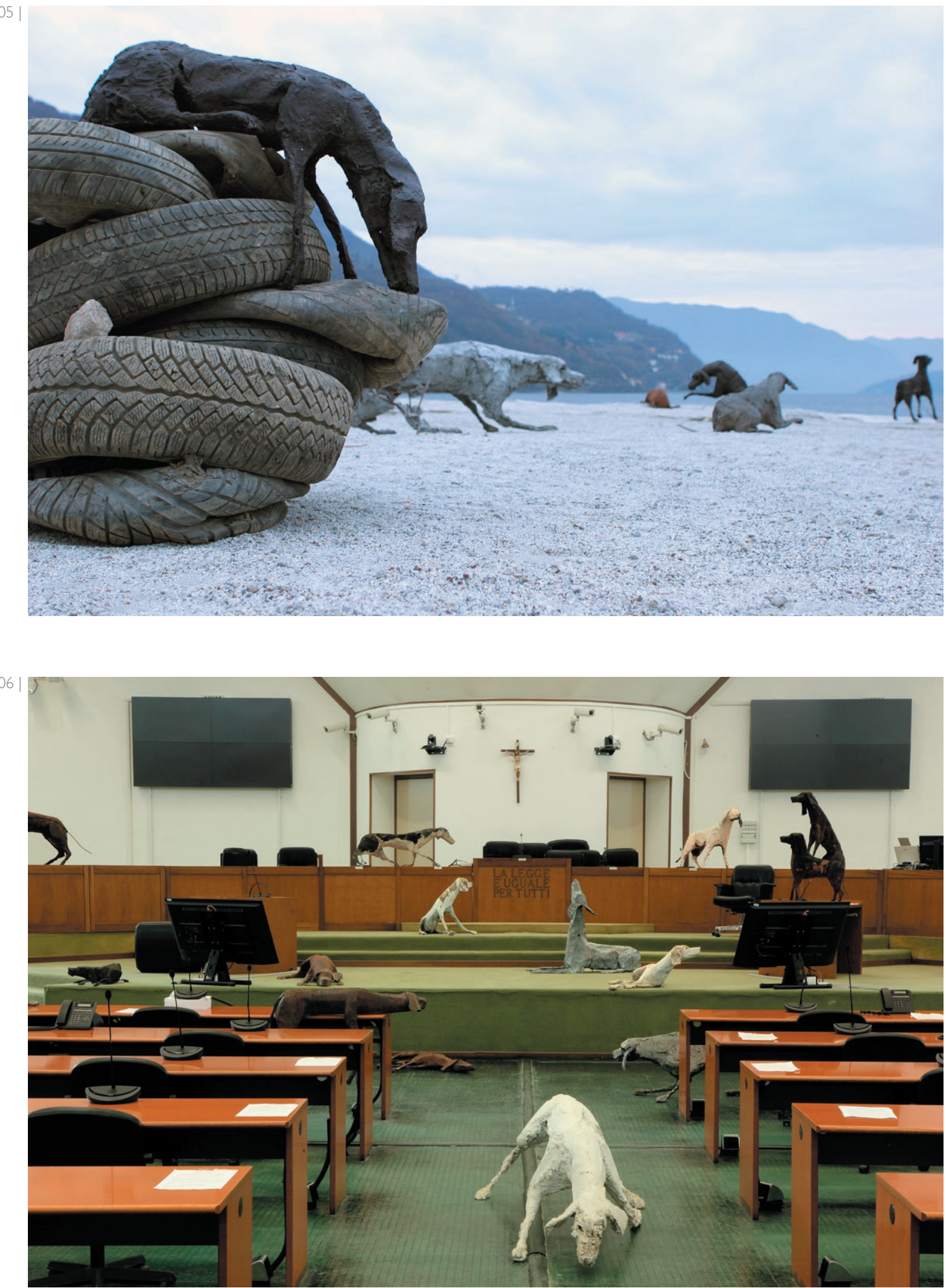

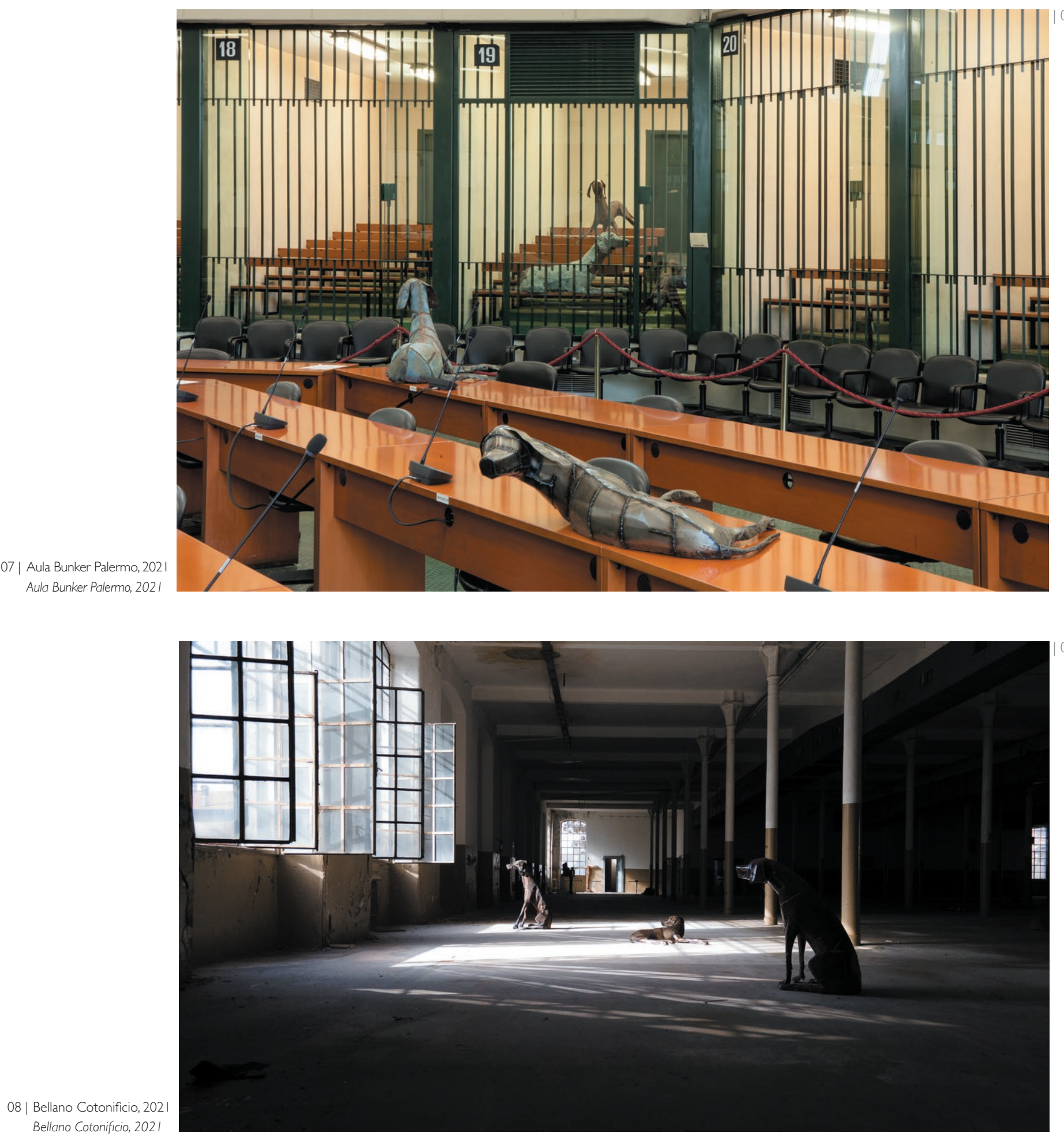


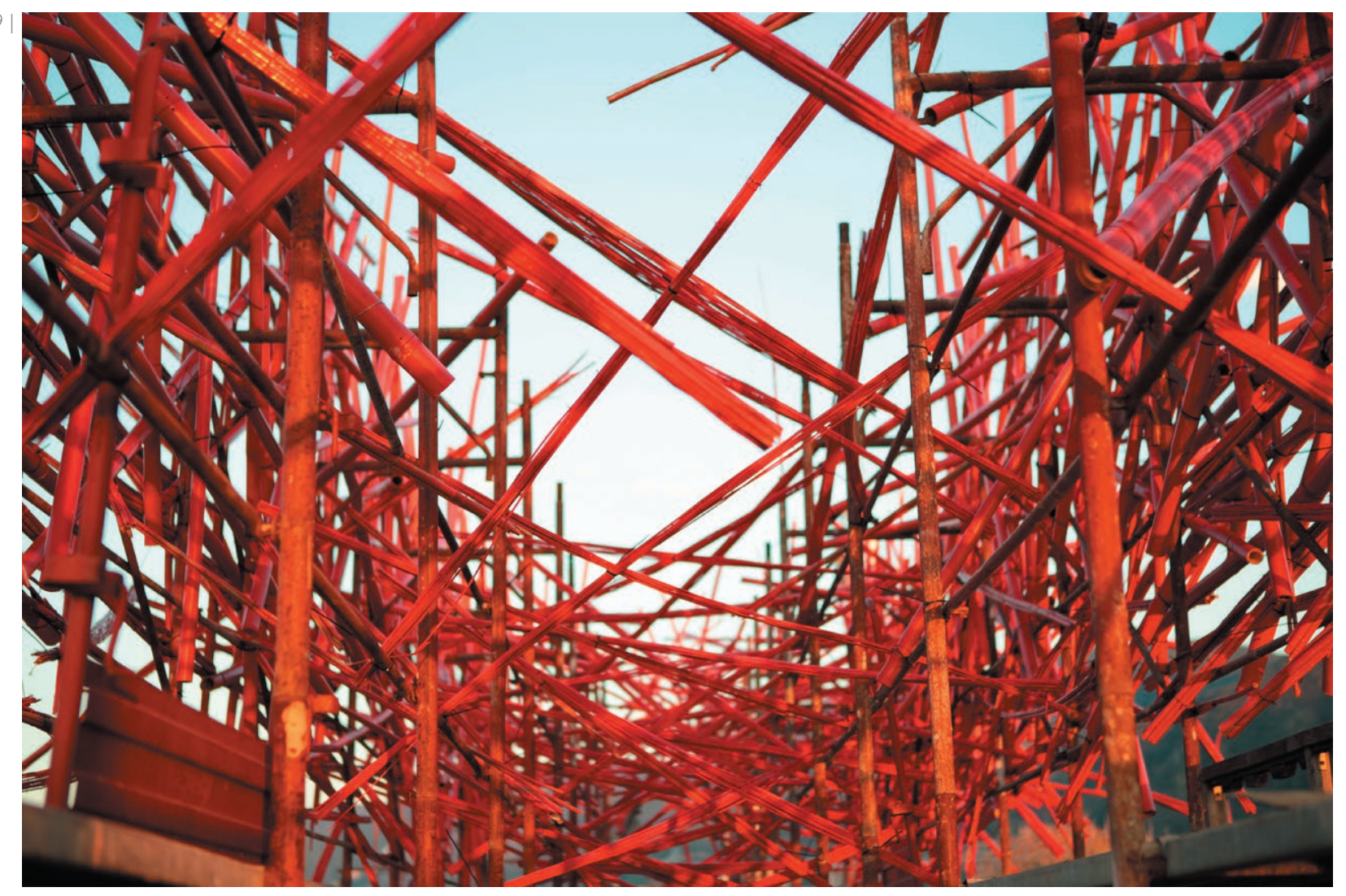

09 | Mediteraneo

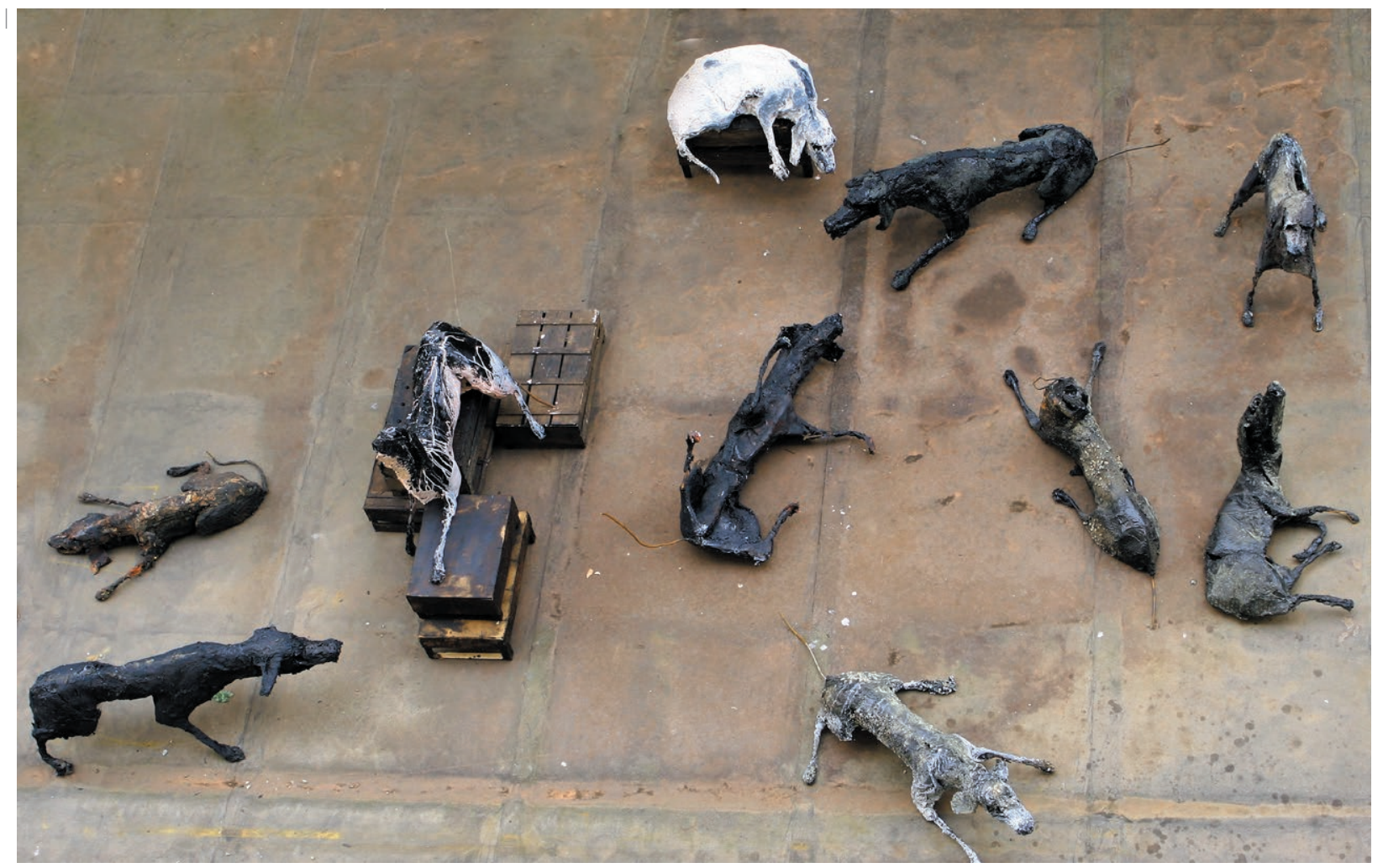

